\title{
Identity and Market for Loyalties Theories: The Case for Free Information Flow in Insurgent Iraq
}

\author{
By
}

\author{
Paul D. Callister ${ }^{1}$
}

\begin{abstract}
"Boys who want to become fighters have to smash their television sets . . . Only then are they considered worthy of becoming mujahideen."
\end{abstract}

\section{Introduction}

When monopoly control over the flow of information is lost, the unavoidable consequence is destabilization. Information flow through a society can be understood as a market-not a market exchanging cash for goods, but loyalty for identity. Hence the market is called the "Market for Loyalties." ${ }^{3}$ The suppliers of identity, who demand loyalty in return, are governments, political parties, opposition groups, insurgents, tribes, religious orders, corporations, militaries, or any other group demanding loyalty (military service, payment of taxes, religious adherence, market share, brand loyalty, etc.) in return for their wares. What these suppliers peddle is identity-roughly the hope, dreams, and aspirations about who one is in relation to society and the past, present, and future. ${ }^{4}$ Loyalty is then exchanged for this identity, and the market for their exchange is found in the information channels of a society. Hence, a loss of control over these channels is a loss of monopoly control over the market. Consequently, Western television and models of education appear as threats in some markets. As one mujahideen unapologetically and unambiguously confessed, "'free secular education'

\footnotetext{
${ }^{1}$ Associate Professor of Law and Director of the Leon E. Bloch Law Library, University of Missouri-Kansas City School of Law. B.A. Brigham Young University, J.D. Cornell Law School, M.S (Library and Information Science) University of Illinois at Urbana-Champaign. This article would not have been written but for the insightful help and skillful expertise of Captain Don Smith, U.S. Army, Foreign Military Studies Office. The author also thanks Prof. Nancy Levit of the UMKC School of Law, Dr. Montgomery McFate, from the Institute for Defense Analyses, his research assistants, Elizabeth BachVan Horn and Ashley Jackson, and the librarians and staff of the UMKC School of Law.

2 Jessica Stern, Terror in the Name of God: Why Religious Militants KiLl 114 (2003)(interview with mujaheed in Lahore, Pakistan).

${ }^{3}$ The theory was initially developed by Monroe E. Price, to whom the author is particularly indebted. See infra note 7.

${ }^{4}$ For discussion of the concept of identity, see infra section entitled, $B$. The Importance of Identity, below.
} 
for all leading to an 'increase in the literacy rate' is the gravest threat to the jihadi groups in Pakistan."

In post-invasion Iraq, Saddam Hussein lost or monopoly control over the information market, where loyalty and identity were exchanged. The consequence was the plummeting of loyalty that former régime could command in exchange for its marketed form of identity. Into this vacuum stepped new sellers, as the populous scrambled to find new suppliers and better exchange rates for identity. Indeed, in many areas the old supplier (Saddam's Baathist party) had been completely swept away, and in others, competitors with the Baathists (such as nationalists, "tribalists," fundamentalist Islamic movements, terrorist cells, etc.) emerged willing to barter at more favorable rates of exchange. The result of the sudden opening of the market is chaotic and violent. New suppliers of identity hawk wares so potent, that the consumer's loyalty extends to martyrdom in the form of suicide bombing (all for a few moments of temporal fame, and bright prospects of rewards in eternity).

The current market for loyalties in Iraq is complicated by an additional characteristic-the impact of tribal structures to limit the number of effective buyers in the marketplace. Tribes function as brokers, restricting, the presence of competing buyers and functioning as resellers of identity in the marketplace. Unlike traditional brokers in markets exchanging cash for goods or services, the costs of changing tribal brokers may lock individuals into tribal units, with significant implications on the market for exchange of loyalty and identity. ${ }^{6}$ Consequently, both the "wholesale" and "retail" markets need to be discussed to understand the implications of radical changes in Iraq's information environment.

The dilemma for the United States is what to do about the new information market in Iraq - to clamp down and re-exert monopoly control, to stand back, laissezfaire-like, and let the market take its natural course, or to somehow manage the slide to equilibrium by carefully eliminating barriers and engineering the emergence of competitors in the market. This article will first present the theoretical underpinning of the market for loyalties in terms of neoclassical economics, emphasizing the importance of identity in this market. In so doing it will apply the theory to understanding many of the instabilities in Iraq and the Middle East. Second, the article suggests implications of the market for loyalties for U.S. policy. The article concludes that despite consideration

\footnotetext{
${ }^{5}$ STERN, supra note 2, at 230 (interview with a militant at a madrassah-a religious school, in Lahore, Pakastan). Apparently others at the school also indicated that "education" was the largest threat. See id.

${ }^{6}$ For example, residents in Baghdad often patronize shops and restarurants of the same tribe. See Rajiv Chandrasekaran, Iraqi Wild Card: Tribal Loyalties Hard to Predict, WASH. Post, Jan. 19, 2003, at A1, available at LEXIS, NEWS Library, WPOST File. To betray one's tribe would have serious repercussions. In fact, when Hussein's sons-in-law returned to Iraq from Jordan, after betraying secrets about Iraqi weapon's program, they were killed not by "police or military, but [by] members of their own tribe seeking to redeem the family's honor." Id. But see, infra note 63 for discussion of instances when tribal relationships are altered or fictionalized.
} 
of tribal intermediation of the information market, which must and can be addressed, US policy is not to win Iraqi loyalty by promulgating its own particular message of identity, but the creation and maintenance of an open and pluralistic market for loyalties within Iraq's information environment. In such a market, diverse identities are sufficiently numerous to insulate the market from potential disruption caused by provocative messages hawked by radical and violent groups. In essence, this Article presents an argument for freedom of speech and information flow based upon market for loyalties theory.

\section{The "Market for Loyalties" and "Identity Theory"}

Market for loyalties theory was originally developed by Monroe Price to explain government behavior in regulating, censoring, and technologically blocking radio, cable and satellite broadcasting. ${ }^{7}$ In a previous paper, the author applied market for loyalties theory to the Internet, focusing on the consequences of loss of monopoly control over information flow which are predicted by application of Price's theory. ${ }^{8}$ While Professor Price has written extensively on the regulation of cable, satellite and radio broadcasting to the Middle East, the author's application of the theory to the loss of monopoly control and the Internet has not previously extended to the Middle East, the war on terrorism, or the occupation of Iraq. The neoclassical elements of Price's economic model and their extension to the loss of monopoly control are summarized below. The essential theory is then applied to tribal societies in the context of wholesale and resale markets. Finally, the validity of such economic analysis to information studies is reviewed.

\footnotetext{
${ }^{7}$ Monroe Price is the Joseph and Sadie Danciger Professor of Law and Director of the Howard M. Squadron Program in Law, Media and Society and a past Dean of the Cardozo School of Law. See, e.g., MonRoE E. PRICE, Media AND SOVEREIGNTY: THE Global INFORMATION REVOLUTION AND ITS Challenge to State Power (2002); Monroe E. Price, The Newness of New Technologies, 22 CARdozo L. ReV. 1885 (2001); Monroe E. Price, The Market for Loyalties and the Uses of Comparative Media Law, in Broadcasting Reform in India: Media LaW from a Global Perspective 93 (1998) (also in Monroe E. Price, The Market for Loyalties and the Uses of Comparative Media Law, 5 CARDOzO J. INT'L \& COMP. L. 445 (1997)[hereinafter Comparative Media Law]); MonRoE E. PRICE, TELEVISION: THE Public SPHERE AND NATIONAL IDENTITy (1995)[hereinafter TeleVISION]; Monroe E. Price, Law, Force and the Russian Media, 13 Cardozo ARTS \& EnT. L.J. 795 (1995); Monroe E. Price, The Market for Loyalties: Electronic Media and the Global Competition for Allegiances, 104 YALE L.J. 667 (1994) [hereinafter, Market for Loyalties].

${ }^{8}$ See Paul D. Callister, The Internet, Regulation and the Market for Loyalties: An Economic Analysis of Transborder Information Flow, 2002 J. LAW, TECH. \& POL'Y 59-107 (applying market for loyalties theory to the break down of monopoly control and the Internet). Monroe Price first considered the implications of the Internet in MEDIA AND SOVEREIGNTY, supra note 7. He has also written about the Internet, but without specific application of market for loyalties theory in MONROE PRICE \& STEFAAN G., VerHulst, SelF-REgulation AND the INTERNET (2005) and Public Diplomacy and the Transformation of International Broadcasting, 21 CARDOZO ARTS \& ENT. L. J. 51 (2003).
} 


\section{A. The Basic Elements of the Market for Loyalties}

The elements of the market for loyalties are familiar to anyone with a background in economics. To understand the application of economic theory to information environments, the following table is helpful:

\begin{tabular}{|l|l|}
\hline Economic Term & Market for Loyalties \\
\hline Sellers & Governments and Power Holders \\
\hline Buyers & Citizens \\
\hline Price/Currency & Loyalty \\
\hline Goods & Identity \\
\hline
\end{tabular}

Table 1--Economic Terms in Market for Loyalties

In the market for loyalties, goods and services are not exchanged for cash, although such elements may be present in the market. Rather, governments and other aspiring power holders demand loyalty in exchange for identity (a connection to the legacy, resources, protection, hopes and aspirations of the groups they represent). To maximize the loyalty (in terms of taxes, votes, product preferences, military service, etc.), it is natural that governments and power holders would seek to exclude competitors from the market through controlling the information channels and communications which permit the market to function. The consequence is a monopolization of the market for loyalties, which is illustrated by the following chart:

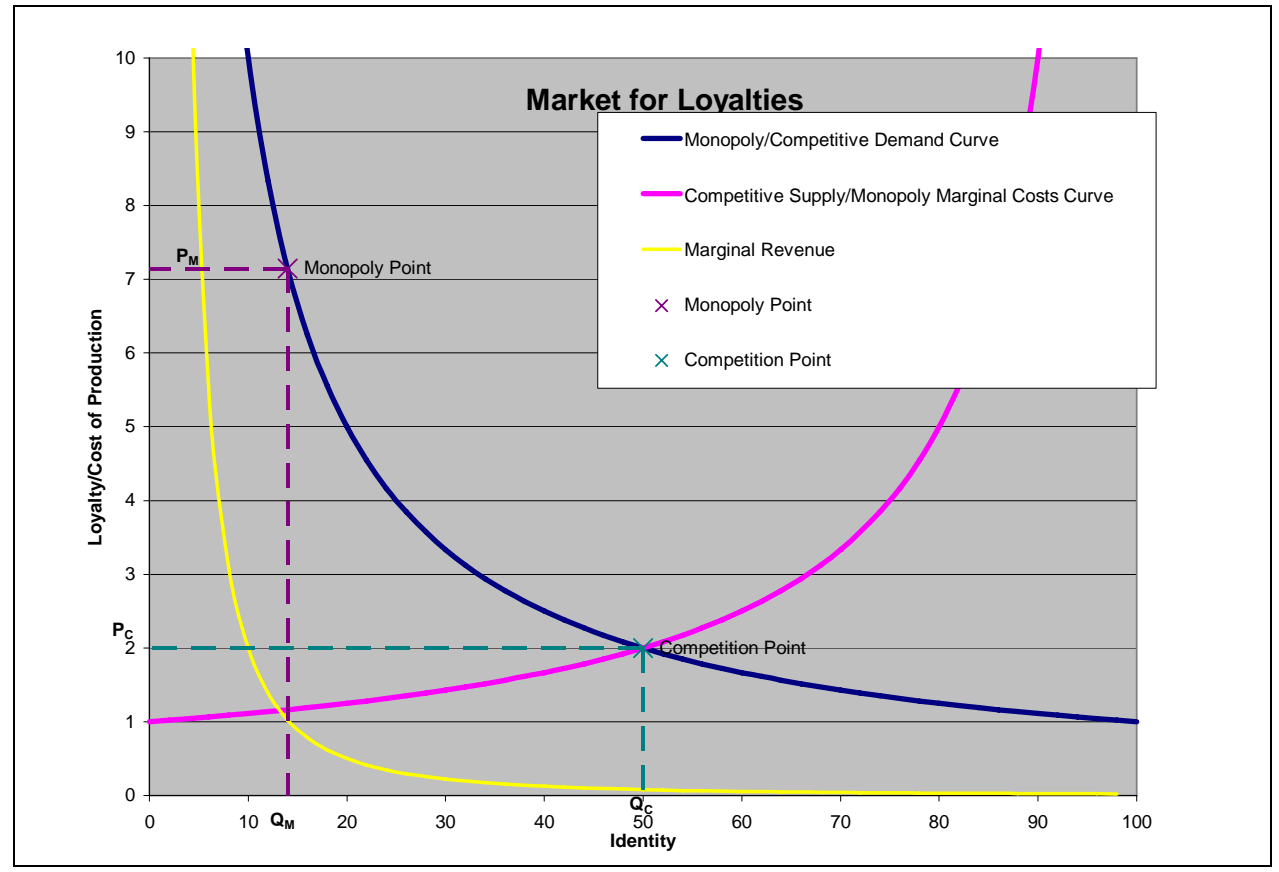

Figure 1-Unitary Demand Curve

If a government has established monopoly control in the market for loyalties by controlling information flow, it is able to get a high price in loyalty in exchange for relatively little output or quantity of identity. See the Monopoly Point in Figure 1 
(represented by points $Q_{m}$ and $P_{m}$ ). The Monopoly Point is determined as a point on the demand curve, directly above the intersection of the Marginal Cost Curve (the same as the competitive supply curve) and the monopolist's Marginal Revenue Curve.

However, if monopoly control is lost, the exchange rate will descend the demand curve to the Competition Point, with the price in loyalty falling to point $P_{c}$ and quantity of identity increasing to point $Q_{c}$. The Competition Point is the intersection of the competitive supply curves and demand curves.

The descent from $P_{m}$ to $P_{c}$, if significant, is destabilizing. It represents the failure of a government or reigning oligarchic powers to raise taxes, enlist soldiers, and otherwise gather support. For example, Western media (rock 'n role and blue jeans) is believed to have weakened resolve of former Soviet citizens to support their Kremlin. ${ }^{9}$ China has also recognized the threat of the influence of Western media as a threat to the loyalty owed by its citizens to the motherland:

International satellite dissemination conducted by Western developed countries threatens the independence and identity of China's national culture. We should seriously deal with this situation. These [cultural] factors include loving the motherland, hard work, advocating industry and thrift, . . . taking a keen interest in science, attaching importance to culture, ... and stressing moral courage. The national spirit contains patriotism, collectivism, hard work [sic] and bravery, defying brutal force and daring to fight .... Precisely because of this, we take seriously the infringement of overseas radio and television and the influence they bring which hampers the national spirit to expand. ${ }^{10}$

\footnotetext{
${ }^{9}$ Comparative Media Law, supra note 7, at 453-54 (citing SUBCOMM. ON INT'L OPERATIONS, HOUSE

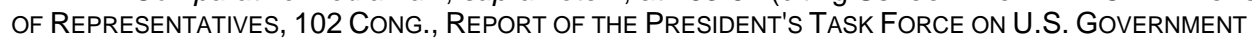
INTERNATIONAL BROADCASTING (Comm. Print 1992)). Ironically, Western media may also have weakened the resolve to support modern democratic institutions.
}

[F]illing the foreign public space with Wheel of Fortune and the throbbing and distracting siren songs of MTV might subvert or inhibit the building of democratic practices. The job of being a citizen in a transitional society would be tough and grueling [sic], demanding full attention to the structure of government and society. An overly zealous commercial culture . . . would pre-empt the development of adequately functional political culture.

TELEVISION, supra note 7, at 22 (referring to a panel discussion at a conference of the American Enterprise Institute for Public Policy Research, The New Global Popular Culture: Is it American? Is it Good for America? Is it Good for the World?, (Mar. 10-11, 1992), Washington, D.C. (organized by Ben Wattenberg, Senior Fellow)). "The concern is whether the diminution of loyalty to traditional government authority as a result of Western media ultimately makes the establishment of new democratic institutions more difficult." Callister, supra note 8, at 86, n.125.

${ }^{10}$ Zhao Shuifu, Foreign Dominance of Chinese Broadcasting - Will Hearts and Minds Follow?, INTERMEDIA, Apr.-May 1994, at 8-9 (emphasis added), quoted in Market for Loyalties, supra note 7, at 676, n.42. China has not chosen to isolate itself from Western culture. Rather, it has exercised paternalistic control over foreign influences. See Callister, supra note 8, at 87, n.126, citing Shuifu, supra at 9 ("This requires us to analyse [sic] foreign culture and differentiate with a serious and scientific attitude, and help audiences to absorb the essence and discard the dross."). 
Media, particularly Western media, can diminish the loyalty commanded by authoritarian states (such as manifest through patriotism, self sacrifice, willingness to fight, etc.), and if extreme can destabilize such a régime.

Not surprisingly, Islamic countries have also been concerned with Western broadcasting. ${ }^{11}$ Indeed, a Kuwaiti government minister blamed the spread of Islamic extremism in his own country on the media:

The justice minister added that after the emergence of globalization and the development of modern media, Western media gained control over societies, including Islamic ones. He indicated that it is obvious that satellite channels are partly responsible for moral corruption in the absence of media censorship, which leads to the transfer and spread of thoughts in all countries. As a result, young men travel with some people to states like Afghanistan, Iraq and others, without their parents or the government being aware of it.

This is due to the thoughts and ideas received through the media and satellite channels, the messages that some radicals send for transmission, and the interviews carried by the satellite channels with some others, or due to these young people's financial capabilities, which allow them to travel and mix with Western cultures that either permit moral corruption or allow the promotion of radicalism. ${ }^{12}$

${ }^{11}$ See, e.g., Cable TV Programmes Should be According to Social, Religious Norms, PAKISTAN PRESS INT'L INFO. SERVICES LTD., May 11, 2005, LEXIS, News Library, Global Newswire File ("Due to Western and Indian channels, our society faces challenge of consumerism and sensuality."); Iran: Editor Calls For Action Against "Blasphemous" Uk-Based Satellite TV, BBC MONITORING INT'L REP., Nov. 23, 2004, LEXIS, News Library, BBC Monitoring: International Reports File ("The editor of a conservative Iranian paper has published a strong condemnation of an unnamed UK-based Persian-language satellite TV. He accused the British government of complicity in broadcasting insults against Islam and suggested that a presenter on the channel should be shot."); Majlis Official Comments on Bill Banning Use of Satellite Programme Receivers, BBC SUMMARY OF WORLD BROADCASTS, Dec. 20, 1994, LEXIS, News Library, BBCMIR File. Corruption is a frequent theme of criticisms of the influence of Western media.

Satellite transmission, broadcasting the programmes of foreign television networks, is not designed to increase the scientific knowledge of nations. Rather it has been developed to mislead youth ... . They sell obscene films either at a very low price or give it to you free of charge, whereas the scientific films are so expensive that one cannot afford to buy them. They [the West] do not transfer their knowledge. They do not transfer their experience of modernizing technology. What they transfer is what drags families into corruption.

Emani-Kashani: West Interest in Transfer Not of Technology But of Corruption, BBC SUMmARY OF WORLD BROADCASTS, Sept. 19, 1994, LEXIS, News Library, BBCMIR File cited in Market for Loyalties, supra note 7, at 676 n.41 (excerpting a prayer sermon delivered by Ayatollah Mohammad Emami-Kashani on September 16, 1994 at Tehran University and broadcast on the Voice of Islamic Republic of Iran).

${ }^{12}$ Kuwaiti Justice Minister Blames Globalized Media for Rise in Youths' Radicalism, BBC WORLDWIDE MONITORING, Jan. 20, 2005, LEXIS, News Library, BBC Monitoring: International Reports File (original source is attributed as Al-Sharq al-Awsat, London, in Arabic 14 Jan 05 p 9). 
The threat perceived by authoritarian states from media is genuine concern.

Specifically the threat is perceived to strike at the heart of the state's ability to command loyalty by diverting loyalties elsewhere. Ironically, Western media is blamed for facilitating accesses and receptiveness to extremist messages.

\section{B. The Importance of Identity}

The concept of identity can be illuminated with respect to the aspirations of sellers in the market for loyalties: "The sellers in the market [for loyalties] are all those for whom myths and dreams and history can somehow be converted into power and wealth-classically states, governments, business groups, and others." ${ }^{13}$ In short, the message of identity may

consist of a party platform, ideology, or national ideals and aspirations. It may be as ephemeral as the hope for a better future or as concrete as the desire of a national homeland. Identity is valuable to buyers as it contains both the legacy of their past history and the promise of their dreams for the future (whether it is for wealth, a better life, or an education).$^{14}$

The connection of the heritage of the past and dreams of a better or more secure future are essential elements of the concept of identity.

Beyond market for loyalties theory, as traditionally applied in media law, identity is emerging as a key component of our understanding of the motivational forces behind terrorism. In her insightful and compelling book, Terrorism in the Name of God: Why Religious Militants Kill, Harvard researcher Jessica Stern expressed the common theme found among religious terrorist groups, based upon interviews with terrorists all over the world:

What seems to be most appealing about militant religious groups-whatever combination of reasons an individual may cite for joining-is the way life is simplified. Good and evil are brought out in stark relief. Life is transformed through action. Martyrdom - the supreme act of heroism and worship-provides the ultimate escape from life's dilemmas, especially for individuals who feel deep alienated and confused, humiliated or desperate. ${ }^{15}$

Stern focuses on alienation, humiliation, demographics, history and territory (each concept serving as a chapter of her book) ${ }^{16}$ to explain the causes or "grievances" that motivate religious terrorism. Each concept is profoundly interconnected with the

${ }^{13}$ Market for Loyalties, supra note 7, at 669 (emphasis added).

${ }^{14}$ Callister, supra note 8, at 83.

${ }^{15}$ STERN, supra note 2, at 6 . For discussion of Stern's methodology, see id. at xxix-xxxi.

${ }^{16} I d$. at ix. "This book is about ... deeper feelings—the alienation, the humiliation, and the greed that fuel terrorism. And it is about how leaders deliberately intensify those feelings to ignite holy wars." ld. xix. 
concept of identity. As described by Stern, "alienation" is the process used by one violent cult in the U.S. to develop the "' in group,' foster group identity, dehumanize the group's purported enemies, and encourage the creation of a 'killer self' capable of murdering large numbers of innocent people." ${ }^{17}$

"Humiliation" and lack of identity are apt descriptions of the profile given by a general from the Palestinian Authority on Hamas suicide bombers:

Young, often a teenager.

He is mentally immature.

There is pressure on him to work.

He can't find a job.

He has no option, and there is no safety net to help him.

He would try to work for the PA [Palestinian Authority] but he doesn't get a job because he has no connections.

He tries to get into Arafat's army, but again, he doesn't have the right connections. ...

He has no girlfriend or fiancée.

On the days he's off, he has no money to go to the disco and pickup girls (even if it were acceptable).

No means for him to enjoy life in any way.

Live has no meaning but pain.

Marriage is not an option .... .

He feels he has lost everything.

The only way out is to find refuge in God.

He goes to the local mosque....

He begins going to the mosque five times a day-even for 4:00 am prayers. ${ }^{18}$

From there, Hamas will identify the troubled youth and gradually recruit him with promises of a blessed afterlife, by telling him that the family names of martyrs are held in the highest respect, and by providing money for his family. ${ }^{19}$ Hamas knows the potency of humiliation as a weapon and identity as a currency, especially among those who have so little of it.

\footnotetext{
${ }^{17}$ Id. at 9 (emphasis added).

${ }^{18} / d$. at 50.

${ }^{19}$ Id. at $50-51$.
} 
In 2003, Laurence lannaccone challenged the popular view that suicide bombers are socially and economically deprived, as well as frustrated, cognitively limited, and psychopathic. $^{20}$

The substantial body of empirical results reviewed or derived by Krueger and Maleckova (2003) thus finds "little direct connection between poverty or [poor] education and participation in terrorism." Moreover, Berrebi (2003) finds that Palestinian suicide bombers have substantially more schooling and better economic backgrounds than the average Palestinian. Berrebi's statistical portrait reaffirms the portrait that emerges from Nassra Hassan's (2001) interviews with potential Palestinian suicide-bombers, which in turn sounds exactly like a quote from the literature on cult converts: "None of [the bombers] were uneducated, desperately poor, simple minded or depressed. Many were middle class and unless, they were fugitives, held paying jobs. . . . Two were sons of millionaires." 21

However, lannaccone also finds that identity and loyalty play important roles in the recruitment of suicide bombers. "Although organizations seek to motivate potential bombers in many ways, the 'crucial factor' is 'loyalty to the group' promoted by 'small cells' and 'countless hours of intense and intimate spiritual training."'22 Indeed,

${ }^{20}$ Laurence R. Iannaccone, The Market for Martyrs 3, 8 (Mercatus Center, George Mason University, Global Prosperity Initiative Working Paper No. 48, 2003), available at http://www.mercatus.org/pdf/materials/822.pdf (paper delivered to the American Economic Association).

${ }^{21}$ Id. at 9 (citing Alan B. Krueger and Jitka Maleckova, Education, Poverty and Terrorism: Is There a Causal Connection?,_J. ECon. PerspeCtives 17 (2003); Claude BerRebi, Evidence About the Link Between Education, Poverty and Terrorism among Palestinians (2003); Nasra Hassan, An Arsenal of Believers, NEW YORKER, __ 2001, at 36-41. A recent book by Robert Pape, based upon compilation and analysis of a database covering every (315) suicide attacks from 1980 through 2003 likewise supports this profile. "Few suicide attackers are social misfits, criminally insane, or professional losers. Most fit a nearly opposite profile: typically they are psychologically normal, have better than average economic prospects for their communities, and are deeply integrated into social networks and emotionally attached to their national communities." ROBERT A. PAPE, DYING TO WIN: THE STRATEGIC LOGIC OF SUICIDE TERRORISM 23 (2004). Like lannaccone, Pape takes the position that suicide campaigns require extensive social networks. See id. at 22 ("suicide terrorist organizations often command broad social support"). Pape also finds that such "terrorism is mainly a response to foreign occupation" and is an extreme strategy for national liberation. $I d$. at 23.

While there is conflicting evidence with respect to suicide bombers, Stern notes that neo-Nazi's attracted less educated youth, but that left-wing groups in Germany and the US attracted "well-educated and wealthy. ..." Stern, supra note 2, at 80 (citing Alan B. Krueger and Jitka Maleckova, The Economics and Education of Suicide Bombers: Does Poverty Cause Terrorism?, NEW REPUBLIC, 24 June 2002, at ). Stern also points out there are considerable differences in education depending upon an operative's place in the hierarchy of the terrorist organization. "One of the problems of the studies conducted so far is that they purport to demonstrate the role of socioeconomic factors on terrorism writ large, rather than for particular groups in a particular place under particular conditions at a particular time." Stern, supra note 2, at 80.

22 IANNACCONE, supra note 20, at 9 (citing David Brooks, The Culture of Martyrdom, 2002 , at 18-20). 
"camaraderie, power, status, honor, identity, purpose, ... powerful emotional experiences, and the prospect of heavenly rewards" are listed as the diverse "output" offered by religious terrorist groups. ${ }^{23}$

Returning to Stern, shifting demographics play an important role in religious terrorism. In Indonesia, demographic factors, specifically government sponsored migration from overpopulated areas to less crowded regions, have tipped religious and ethnic balances and resulted in violence. ${ }^{24}$ In addition, considerable socioeconomic development in Indonesia has produced a new phenomenon--an urban middle class, which is mostly Moslem. ${ }^{25}$ This new class has had to face the onslaught of modern life, which can be destabilizing. Stern comments:

[M]odernity itself creates confusion and fear in part because of a surfeit of choice. ... Modernity introduces a world where the potential future paths are so varied, so unknown, and the lack of authority is so great that individuals seek assurance and comfort in elimination of the unsettling possibilities. Too much choice, especially regarding identity, can be overwhelming and even frightening. Under these circumstances, some people crave closing off options; they crave discipline imposed from the outside. The "strictness" of militant religious groups-and the clarity they offer and self and other-is a part of the appeal. ${ }^{26}$

In other words, the choices suddenly offered by an "opening" of society, ether democratically or economically, can be quite unsettling, particularly to the all-important sense of identity. This problem is particularly compounded when migration or other factors alter the existing power structure of the various ethnic and religious groups within a community. Such factors could explain why Palestinian suicide bombers are recruited from upper classes of society. ${ }^{27}$

The territorial conflict in Kashmir, as described by Stern, concerns far more than the physical placement of a border or even nationalism. The struggle is deeply infused with a sense of recovering lost Islamic identity. One ex-militant explains the sense of hurt: "Muslims have been overpowered by the West. Our ego hurts." ${ }^{28}$ Kashmir was

${ }^{23}$ IANNACCONE, supra note 20 , at 16 . Iannaccone also notes that "a bundled collection of products" or benefits enable terrorist groups to recruit a broader range of members. Id.

${ }^{24}$ STERN, supra note 2, at 63.

${ }^{25}$ Id. at 69 .

${ }^{26}$ Id.

${ }^{27}$ See supra notes 20-22 and accompanying text.

28 STERN, supra note 2, at 135. From the same ex-militant,

India's repression and occupation of Kashmir were factors for us. . . But nationalism is only part of what causes Islamic militancy. This wasn't a fight for freedom, at least for me. It was a civilizational battle. . . . You have to understand: resolving the nationalist conflict won't end the violence. The goal is much bigger-to recover the golden age of Islam. Nationalism is only part of the picture. 
just one form of expression of the pain. Beyond physical boundaries and historical claims to homelands, the battle is being fought over the territory of identity. Stern captures the sentiments well, "The bottom line, I now understood, is that purifying the world through war is addictive. Holy war intensifies the boundaries between Us and Them, satisfying the inherently human longing for a clear identity and a define purpose in life. . .."29 As with all of the other factors, territoriality is but another form of expression of the quest for identity.

In addition to the factors, of alienation, humiliation, demographics, and territoriality, Montgomery McFate, ${ }^{30}$ and Andrea Jackson ${ }^{31}$ in a recent paper point to the relationship of ideology and narrative in forming group identity and inculcating loyalty. Within Iraq, insurgent groups pushing potent ideologies supply "identity, purpose, and community in addition to physical economic and psychological security." ${ }^{32}$ With respect to those ideologies, "[n]arratives are central to the representation of identity, particularly the collective identity of groups such as religions, nations, and cultures. Stories about a community's history provide models of how actions and consequences are linked, and are often the basis for strategies, actions, and interpretation of the intentions of actions." ${ }^{33}$ For instance, despite Quaranic prohibitions, Al-Qaida members have referred to a story about the Prophet Muhammad's betrayal by a Jewish tribe, known as the Banu Qurayza, for negotiating with his enemies during the siege of Medina [check name of city] in 627 A.D., and the subsequent beheading all 600 of the tribe's men, as modern justification for decapitating non-Muslims. ${ }^{34}$ Indeed such narratives have operated to undermine US efforts at democracy-building in Iraq:

To defeat the insurgent narratives, the Coalition must generate a strongercounternarrative. Unfortunately, the main themes of the Coalition's message -

Id. at 136.

${ }^{29}$ Id. at 137.

${ }^{30}$ Dr. Mongomery McFate is an analyst with the Joint Advanced Warfighting Program, Institute for Defense AnalysesInstitute for Defense Analyses.

${ }^{31}$ Andrea Jackson is the Director of Research and Training at Lincoln Group in Washington, D.C.

${ }^{32}$ Montgomery McFate \& Andrea V. Jackson, The "Object Beyond War": Counterinsurgency and the Four Tools of Political Competition, Millitary Rev. (forthcoming publication Jan.-Feb. 2006, at (currently p. 16 of the manuscript on file with author).

${ }^{33}$ Id. Saddam Hussein was also adept at manipulating ideology and "narrative" to meet his ends:

Saddam tried to erase tribal culture and influence and bind all of Iraq'a diverse groups into one new culture by creating a new Iraqi identity - an identity shaped by Iraq's 6,000-year-old culture and traditions, a loyalty that owes all status, benefits and achievements to Sadadam alone.

Judith Yaphe, Tribalism in Iraq, the Old and the New, 7 MIDDLE E. POL'Y 51 (2000), available at eLibrary.

${ }^{34}$ Mohamad Bazzi, Waging 'Holy' War, Scholars Decry Ghastly Tactic; Beheadings Gain Widespread Attention, But They Have No Legitimate Basis In Quranic Ideology, NEWSDAY (New York) June 24, 2004, at A4, available at LEXIS, News library, Newsdy file. 
freedom and democracy - do not resonate well with the population. In Iraq, freedom is associated with chaos, and chaos has a particularly negative valance that is expressed in the proverb "better a thousand years of oppression than a single day of anarchy." . . . After witnessing unlawful, disorderly behavior, Iraqis will occasionally joke, "Ah, so this is democracy." 35

In the end, ideology in the context of cultural, religious and national narrative serves as an important tool in the merchandizing of identity, and consolidating loyalty, which often is expressed in violent forms of action. "The movement's ideology not only clarifies their tribulations, but also provides a course of action to remedy those ills." ${ }^{36}$ Accordingly, the relationship of identity, ideology and narrative are essential to the application of market for loyalties theory in Iraq.

The summation of alienation, humiliation, demographics, territory, ${ }^{37}$ ideology, and narrative as factors of identity reflect the broader, psychological aspect of identity. From Oxford English Dictionary, identity is defined: "Belonging or relating to identity ... , as in identity crisis, a phase of varying severity undergone by an individual in his need to establish his identity in relation to his associates and society as part of the process of maturing." ${ }^{38}$ It is the relationships to world at large, or lack thereof, that creates an identity crisis and an opportunity to command high loyalty prices-such as suicide bombing, service in a militia, and the hardships and risks of life as a terrorist or insurgent. Consequently, understanding the dynamics of human behavior with respect to identity in the context of market for loyalties theory can provide valuable insight.

\section{Elasticity and the Consequences of De-Monopolization}

Besides the basic paradigm of the market, market for loyalties theory provides additional tools for understanding the impact of loss of monopoly control over the market, such as in post-war Iraq. Particularly helpful is the economic concept of elasticity.

\section{The Basics of Elasticity}

The size of the drop in loyalty as a market is de-monopolized depends upon the elasticity of the demand curve. Assuming equivalent scaling of $X$ (identity) and $Y$ (loyalty) axes, demand curves that are relatively steep--meaning relatively small increase in quantity of identity results in a significant drop in price of loyalty--are considered inelastic. On the other hand, relatively flat demand curves are said to be

\footnotetext{
${ }^{35}$ McFate \& Jackson, supra note 32, at 20. "Democracy is also problematic as an effective ideology because Islam forms the basis for conceptions of government and authority (despite the secular views of Many Iraqis). The Islamic concept of sovereignty is ground in the notion that human beings are mere executors of god's will." Id. at 20-21.

${ }^{36}$ McFate \& Jackson, supra note 32, at 16.

${ }^{37}$ See supra note 16 and accompanying text.

${ }^{38}$ OXFORD ENGLISH DictionARY (online ed.)( $2^{\text {nd }}$ ed. 1989)(definition $10 \mathrm{c}$ for identity).
} 
elastic: increases in the quantity of product (identity) have only a small negative effect on the loyalty (price). A demand curve where drops in loyalty equate to increases in identity are said to be unitary.

For instance, the demand curve in Figure 1, is unitary. At the Monopoly Point, $Q_{m}$ (for the quantity of identity at the Monopoly Point) equals 14 , and $P_{m}$ (for the price in loyalty) equals 7.14 , for a total revenue of 100 units of loyalty. At the Competitive Point, $Q_{c}$ equals 50 , and $P_{c}$ is 2 , also for a total revenue of 100 units. Indeed every point along the demand curve produces total revenue of 100 loyalty units. Consequently, the curve is said to be unitary with respect to the Monopoly and Competitive Points because the total revenue in the market is unaffected by the drop in loyalty as a result of an increase in identity production.

In contrast, the demand curve illustrated in Figure 2 below is elastic, because an increase in the supply of identity, and corresponding decrease in the price of identity actually results in increased total revenues as the market descends the demand curve towards the competition point.

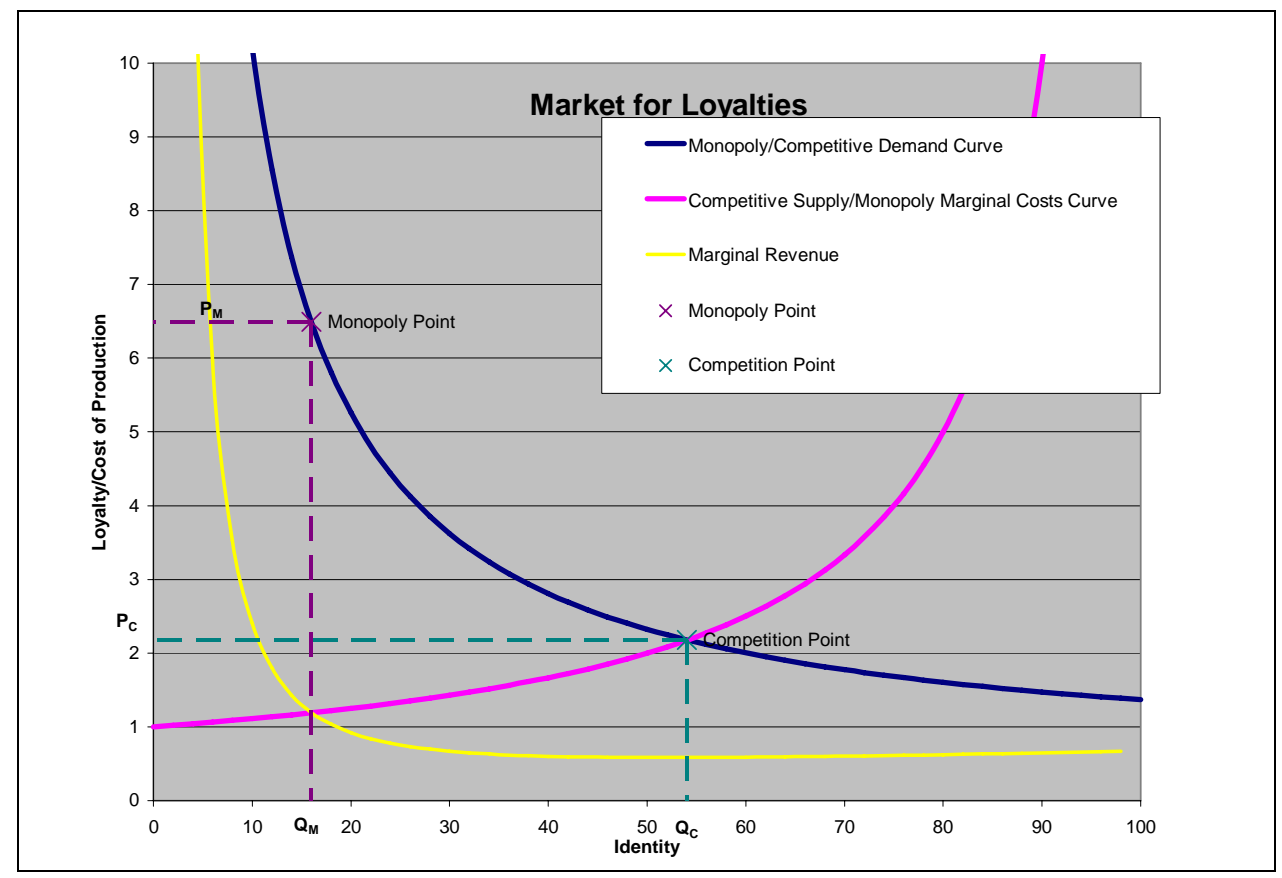

Figure 2--Elastic Demand Curve

In the example above, revenue at the Monopoly Point is $Q_{m} \times P_{m}$ or $(16 \times 6.49)$, which equals total revenue of 103.87 units of loyalty for the monopolist. However, for the Competition Point, $Q_{c} \times P_{c}$ or $(54 \times 2.18)$, which equals total revenue of 117.76 units of loyalty for all of the competitors in the de-monopolized market. The increased quantity of identity has resulted in increased total loyalty and the demand curve is said 
to be elastic (since total revenues respond positively to increased supply). It is also possible to create scenarios with inelastic demand curves.

In the example using Figure 1 above, the price in loyalty fell from 7.14 to 2 (or 5.14 loyalty units) when the market reached competitive equilibrium. In contrast, in Figure 2, the price of loyalty fell from 6.49 to 2.18 (or a total loss of 4.31 ). The loss in the price in loyalty as a market reaches equilibrium is less significant with a greater degree of elasticity. The trauma caused by diminished loyalty is lessened with a more elastic demand curve. Consequently, understanding the conditions effecting the elasticity of demand curves is important to understanding the consequences of understand de-monopolization of any information market. All markets, including the market for loyalties, are not equally affected by a loss of monopoly control.

\section{Factors Affecting Elasticity}

Four factors affect elasticity: the number of substitute products (or identities) in the market and their closeness to the good in question; effects from marginal consumers; complications from wholesale and retail marketing; and the temporal, informational, and transaction costs necessary for consumers to learn about and take advantage of competing products.

\section{i. Presence of Substitutes}

The argument that elasticity or stability increases with additional substitutes was demonstrated in economic literature in 1926 by the Italian economist Marco Fanno. ${ }^{39}$ "Two goods are substitutes if a rise in the price of once causes an increase in demand for the other." ${ }^{\circ 0}$ Essentially, the greater the number of substitutes for identity competing

\footnotetext{
${ }^{39}$ Marco Fanno, Contributo Alla Teoria Economica dei Beni Succdanei, 2 ANNALI DI EconomIA 331 (1925-26). Although the author was unable to find an English translation of this important work, a shorter version was originally published in German. Marco Fanno, Die Elastizitat der Nachfrage nach Ersatzgu tern, ZEITSCRIFT FUR NATIONALOKONOMIE, 1939, at 51-74. An English version of Fanno's translation of this article exists. See Marco Fanno, The Elasticity of Demand of Substitute Goods, 3 ITALIAN ECON. PAPERS 99 (1998). Fanno's conclusions, following rigorous theoretical analysis, are made with respect to markets with two competing substitute goods. However, markets with multiple substitutes would have even greater elasticity. Fanno notes:

[l]t also applies to the instance in which a good may have more than one substitute, that is for the instance of more than two goods. In this case the action of each of them accrues with the others and the elasticity of demand for each of them is, other conditions being equal, all the greater the number of its substitutes.

Id., at 115. The importance of Fanno's contribution has been recognized in American economic literature. Carl L. Alsberg, Economic Aspects of Adulteration and Imitation, 46 Q. J. Econ. 1 (1931). See generally, Paul D. Callister, supra note 8, at 97, n.177.

${ }^{40}$ Douglas A. L. Auld, ET AL., American Dictionary of Economics 306 ( $2^{\text {nd }}$ ed.1983)(under entry for "Substitutes"). An exception to this rule occurs in the instance of "inferior" substitutes. When the price of an inferior or weak substitute falls, it may have the unexpected effect of increasing demand for its substitute. See H. Fabian Underhill, An Overlooked Lesson in Prices of Substitute Goods, 3 Econ. Educ. 136-37 (1972).
} 
in the market, the greater the elasticity of the market, and consequently, the less dramatic any drop in loyalty as a result of de-monopolization. In addition, how close the substitutes are to the original product (e.g., Coke is a close substitute of Pepsi but not of orange juice) is also an important factor. ${ }^{41}$ Close substitutes make the demand curve more elastic. $^{42}$

A previous article by the author describes, in the form of a function, the stabilizing effect of substitute identities in the market:

$$
i=f\left(\frac{k}{p}\right)
$$

where $i$ is the instability, $k$ represents the level of new competing identities being introduced, and $p$ is the penetration of previously competing identities, or substitutes, into the market. Eventually, in a state that opens itself to competing identities, if $p$ were to approach infinity, the level of disturbance will grow infinitesimally small (at least with respect to the instability caused solely by the introduction of new identities):

$$
\lim _{p \rightarrow \infty}\left(\frac{k}{p}\right)=0
$$

Hence, a state in which a diversity of identities flourishes is a supremely stable one, at least mathematically, with respect to the instability caused by the introduction of new identities. ${ }^{43}$ This means that the consequence of a new political newspaper, radio station, web site, etc. in the US is relatively inconsequential with respect to diminishment of loyalties in the market, especially compared to the impact of a new media source in a country like China.

If it is true that the most stable states have reached equilibrium in the information market, with many groups providing identity, and a relatively stable price in terms of loyalty, why then does the overthrow of repressive regime often result in such violence and chaos (such as in Iraq)? Why do information markets ever slide back toward

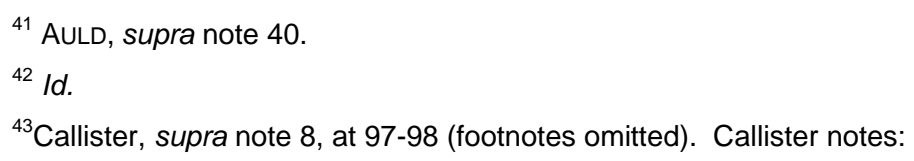

This is because a portion of the formula, namely other factors which impact elasticity and instability are unknown. All that is known is that the instability resulting from the introduction of new identities will approach zero, if in theory only, the number of previously introduced identities approaches infinity. 
monopolization (as in the Weimar Republic following WWII)? To answer these questions, other factors must be considered.

\section{ii. Marginal Consumers}

The number of consumers (purchasers of identity) does not remain constant with the addition of substitutes (additional identities). Preferences for particular identity products and lower prices may induce bystanders to enter the market to buy, thereby increasing demand and pushing up price (in terms of loyalty) higher than it would have otherwise been. This is true because "as there are more and more consumers in the market, there is a greater likelihood that one of those consumers will have a willingness to pay value a little less--but very close--to the market [or offered] price of the good." ${ }^{44}$ Such buyers are known as marginal consumers. ${ }^{45}$

The important question in Iraq is whether de-monopolization of the information market is introducing any new consumers-the greater the number of consumers, the more marginal consumers, increasing demand, there will be. Since the Baathist party favored Sunni and tended to exclude Shi'a and Kurds (who risk their lives to participate in their own insurgencies in pre-occupied Iraq), the number of marginal consumers of identity in the marketplace has arguably increased by the fall of the Baathists, thereby strengthening demand, and decreasing elasticity. Consequently, loss in the price of loyalty, as brought about by de-monopolization, may not result in as drastic an effect. The price, in terms of loyalty, which various groups may demand for identity may still be quite high (a prerequisite for suicide bombers and the recruiting of insurgents). As shall be discussed below, this factor may be compounded by the action of exclusive dealing agreements between suppliers of identity and tribal retailers.

${ }^{44}$ W. RoBert ReEd \& MAX SchanzenBach, The Incredible Information Contained in Prices: Part II, in PRICES AND INFORMATION: A SIMPLE FRAMEWORK FOR UNDERSTANDING ECONOMICS, ch. 6 (1996), http://www.ou.edu/class/econ3003/book/area1c6.html.

${ }^{45}$ See, generally, William Novshek \& Hugo Sonnenschein, Marginal Consumers and Neoclassical Demand Theory, 87 J. POL. ECON. 1368 (1979). The consequences of an increasing number of consumers, including marginal consumers is explained to challenge neoclassical economics, which typically only considers aggregate income and substitution effects (i.e., with respect to a constant number of consumers and buyers).

Ask any economist to explain the elasticity of demand for a product and it is likely he will speak not only of income and substitution effects but also of "marginal consumers" who have reservation prices in the neighborhood of the existing price. Nevertheless, most textbook aggregate demand analysis at the advanced level ignores marginal consumers when describing price-induced changes in the demand for a single commodity. This is because, with a finite number of consumers, an infinitesimal change in price will typically not change the number of consumers with positive demand for a commodity; thus all changes in demand are properly explained by summing the neoclassical income and substitution effects.

Id. at 1368-69. However, with a continuous number of consumers, the effect of marginal consumers cannot be ignored. See id. 


\section{iii. Wholesale and Retail Markets}

Retail markets complicate economic analysis by the imposition of vertical restraints on competition to maximize the profits of wholesale suppliers. ${ }^{46}$ Such restraints include retail price floors, exclusive territorial rights, minimum volume requirements, and franchise fees (in addition to wholesale product prices). ${ }^{47}$ Exclusive dealing agreements between suppliers and retailers are also forms of vertical restraints, although there is no formal vertical integration, as when a single firm undertakes "successive stages in the process of production [and distribution] of a particular good."

In Iraq, tribes have functioned as mediators between their members and Saddam Hussein's régime. "After the [First Gulf] war, when Saddam felt threatened by the weakening of law and order and the potential threat to his regime, he resurrected tribal rule. He rewarded the loyalty of tribal leaders by allowing tribal law to prevail in any areas and bestowing on them guns, cars and privileges. In return, they acknowledged his leadership." ${ }^{49}$ Such tribal leaders act as retailers and brokers. Like brokers they tend to capture their constituents (since they impose high transaction costs for leaving). ${ }^{50}$ However, it is far from clear that they receive a commission (or a fixed percentage) of the gross sales price (loyalty) for their services. ${ }^{51}$ Rather, they exchange loyalty and identity just as their suppliers (Baathists, Shi'a religious groups, nationalists, etc.) do. The nature of the market can be explained:

A chief . . . has to prove himself more able to command than his kinsmen; then, however strong the moral and symbolic authority of the chiefship, he has to maintain his personal position not only by performing the specific functions of chiefship, but by rewarding his followers, if not with booty, at list with lavish entertainment and hospitality; otherwise they may abandon him and support a rival, even the chief of another tribe. . . . A chief has duties to both government and followers, and his position is close to that of feudal lord. Typically he collects tax and military levies, and maintains order for the government, while for his

${ }^{46}$ G.F. Mathewson \& R.A. Winter, An Economic Theory of Vertical Restraints, 15 RAND J. EcoN. 27, 28 (1984).

${ }^{47}$ Id. at $27-28$.

${ }^{48}$ AULD, ET AL, supra note 40, at 333 (under the entry for "vertical integration").

${ }^{49}$ Yaphe, supra note 33.

${ }^{50}$ See supra note 6 and accompanying text.

${ }^{51}$ This distinction is important because the incentives for brokers tend to maximize volume of market traffic rather than the highest price for the seller. See STEVEN D. LEVITT \& STEPHEN J. DUBNER, FREAKONOMICS: A ROUGE ECONOMIST EXPLORES THE HIDDEN SIDE OF EVERYTHING 8-9 (2005). Retailers, on the other hand, must optimize profits with respect to their own costs and must consider both the sales price and volume in their calculus. 
followers he conducts external political relations, adjudicates disputes, and (for nomads) allocates pastures and co-ordinates migrations. ${ }^{52}$

In essence, the sheik serves as the retailer between the members of his tribe and the state. In Iraq, tribal affiliations determine political appointments, career opportunities, and social relationships. ${ }^{53}$ Furthermore, agreements of tribal leaders with suppliers tend to be exclusive, as evidenced by the fact that police units in Iraq tend to be dominated by single tribes. ${ }^{54}$ The consequences of exclusivity are discussed below.

\section{a. Exclusive Dealing with Consumer Mobility}

The consequence of exclusive dealing agreements is greater inelasticity, ${ }^{55}$ and more instability upon destabilization. The competitive dampening effect of exclusive dealing contracts on retail markets is illustrated by two different scenarios in which there are two suppliers with two products (identities). In the first scenario, two identity wholesalers have entered into exclusive contracts with two tribal retailers. Over the period of time (represented by points $A$ and $B$ ), Identity Wholesaler 1 reduces its loyalty price for Identity Product 1 by twenty units, and so does Tribal Retailer 1 (per agreement) ${ }^{56}$ but Identity Wholesaler 2 makes no such change in price. Assume for purposes of illustration that tribal members can move between tribes. ${ }^{57}$ Tribal Retailer 2 is motivated to reduce its price by a little less than 20 units (a 20-unit reduction would leave Tribal Retailer 2 with no margin) to avoid losing customers to Tribal Retailer 1.

${ }^{52}$ Richard Tapper, Introduction, in THE CONFLICT OF TRIBE AND STATE IN IRAN AND AFGHANISTAN 56 (Richard Tapper, ed. 1983). Tapper contrasts the chief with brigands and khans "who [have] gained power through leading a faction but must legitimise [sic] it by 'tying the knot' of a linage group." Id. at 5757.

${ }^{53}$ See supra note 6 and accompanying text.

${ }^{54}$ See McFate \& Jackson, supra note 32, at 12 (90\% of police in Mosul were from the Al Jaburi Tribe). In addition, Saddam Hussein placed control of key security units and intelligence agencies in his own tribe, the Bayajat. See Yaphe, supra note 33, at __. Not only does the supplier (government) agree to exclusively use a particular tribe, but Islamic tradition reinforces the exclusivity of loyalty. See discussion of the Banu Qurayza tribe, supra note 34, and accompanying text.

${ }^{55}$ See Y. Joseph Lin, The Dampening-of-Competition Effect of Exclusive Dealing, 34 J. INDUS. ECON. 209, 210 (1990)("[T]he perceived demands of the manufacturers are rendered more inelastic under exclusive dealing, much as if the products had been made more differentiated."). The closeness or nondifferentiation of substitutes is an important factor in determining elasticity. See supra notes 41-42 and accompanying text.

${ }^{56}$ The assumption is that a shrewd wholesaler would not agree to lower its price to its retailers without assurances of corresponding reduction in retail sales prices for the same product to increase demand.

${ }^{57}$ If the opposite were true (i.e., tribal members could not switch allegiance), the net result would be even less, not more elasticity with respect to the wholesale market (wholesalers could not expect greater revenues in response to increased demand). See infra note 63 and accompanying text. 
The Retail Product and Whole Sale Product demand curves (between points $A$ and $B$ below) illustrate the intuitive economic outcomes. ${ }^{58}$

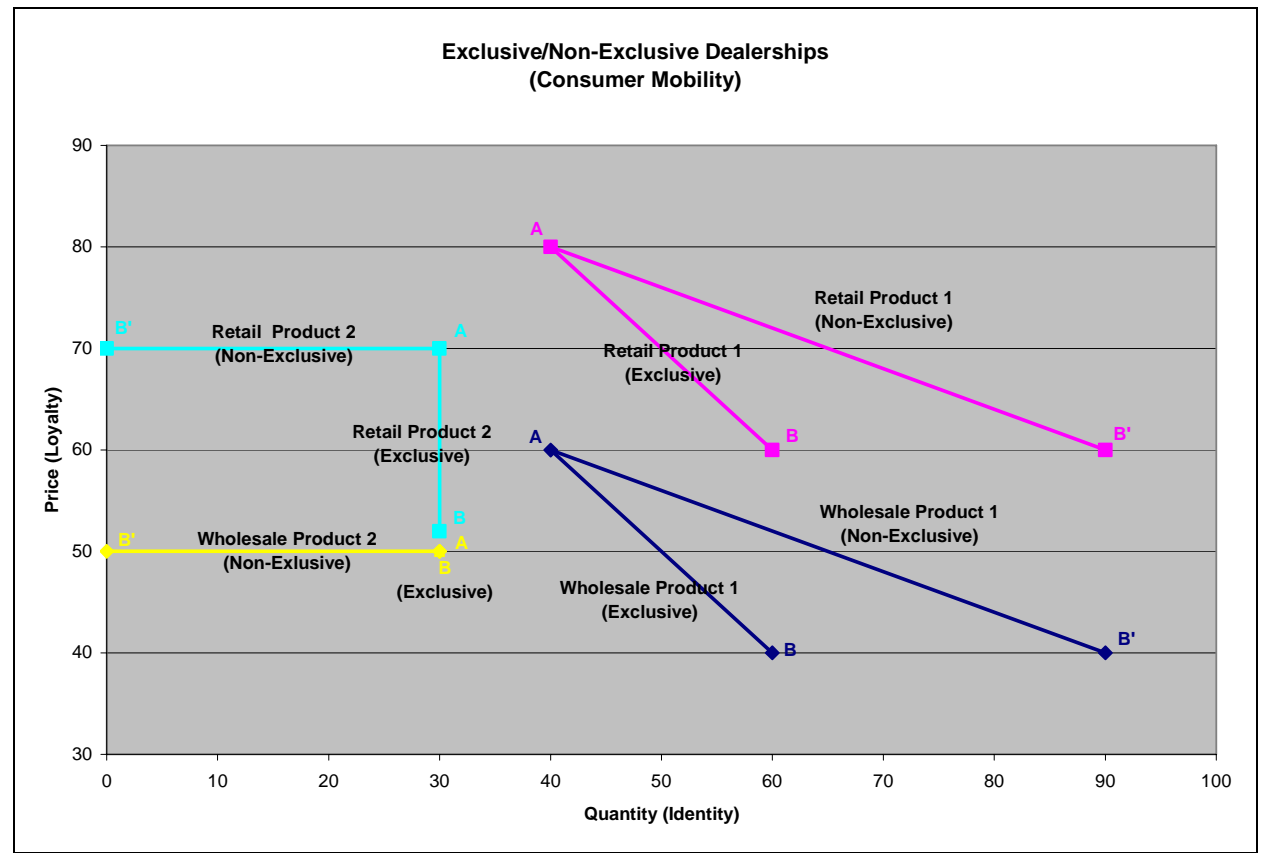

Figure 3

Note, that in this example, the difference between $B$ and $B^{\prime}$ for Retail Product 1 (of 30 units) corresponds to the reduction in units sold for $B$ to $B^{\prime}$ for Retail Product 2.

The loyalty revenues for Tribal Retailers 1 and 2 can be summarized:

\begin{tabular}{|c|c|c|c|c|c|c|c|c|}
\hline \multirow[b]{3}{*}{ Retailer 1} & \multicolumn{4}{|c|}{$\begin{array}{l}\text { Loyalty Revenue at A } \\
\text { (Before Wholesale Price Reduction) }\end{array}$} & \multicolumn{4}{|c|}{$\begin{array}{l}\text { Loyalty Revenue at B } \\
\text { (After Wholesale Price Reduction) }\end{array}$} \\
\hline & \multicolumn{2}{|l|}{ Product 1} & \multicolumn{2}{|l|}{ Product 2} & \multicolumn{2}{|l|}{ Product 1} & \multicolumn{2}{|l|}{ Product 2} \\
\hline & $(40 \times 80)$ & 3200 & & & $(60 \times 60)$ & 3600 & & \\
\hline Retailer 2 & & & $(70 \times 30)$ & 2100 & & & $(52 \times 30)$ & 1560 \\
\hline Total Revenue & 5300 & & & & 5160 & & & \\
\hline
\end{tabular}

Table 2--Inelasticity of Exclusive Dealing

While the revenue for Product 1 increases (by 400 units of loyalty), the total revenues fall from (5300 to 5160) in response to changes in wholesale pricing. Consequently, nonexclusive dealing retail arrangements tend to promote inelasticity in the market. ${ }^{59}$

\footnotetext{
${ }^{58}$ Figure is based on Lin's intuitive example. Lin, supra note 55, at 210-11.

${ }^{59}$ A mitigating factor may affect the inelasticity of the retailer's demand curve in an exclusive dealing arrangement. When dealers only sell one product, "there are always more dealers under
} 


\section{b. Non-Exclusive Dealing}

On the other hand, if Identity Wholesalers have not entered into exclusive agreements, and both Tribal Retail Dealers sold both Identity Products 1 and 2, then neither Tribal Retailer will have any incentive to cut prices on Product 2, because neither will lose customers who switch to Identity Product 1. Assuming that the retail loyalty price for Product 1 is reduced (per agreement with the Wholesaler), ${ }^{60}$ the shift of buyers to Identity Product 1 will increase the quantity of Identity Product 1 sold and produce a more elastic demand curve. The sales of Identity Product 2 will likely disappear. See points $A$ to $B$ ' on Figure 3, for both products. In this scenario, loyalty revenues for the Tribal Retailers can be summarized:

\begin{tabular}{|c|c|c|c|c|c|c|c|c|}
\hline \multirow[b]{3}{*}{ Retailer 1} & \multicolumn{4}{|c|}{$\begin{array}{l}\text { Loyalty Revenue at A } \\
\text { (Before Wholesale Price Reduction) }\end{array}$} & \multicolumn{4}{|c|}{$\begin{array}{l}\text { Loyalty Revenue at B' } \\
\text { (After Wholesale Price Reduction) }\end{array}$} \\
\hline & \multicolumn{2}{|l|}{ Product 1} & \multicolumn{2}{|l|}{ Product 2} & \multicolumn{2}{|l|}{ Product 1} & \multicolumn{2}{|l|}{ Product 2} \\
\hline & $(20 \times 80)$ & 1600 & $(20 \times 80)$ & 1600 & $(45 \times 60)$ & 2700 & $(45 \times 60)$ & 2700 \\
\hline Retailer 2 & $(35 \times 30)$ & 1050 & $(35 \times 30)$ & 1050 & $(0 \times 70)$ & 0 & $(0 \times 70)$ & 0 \\
\hline Total Revenue & \multicolumn{4}{|c|}{5300} & \multicolumn{4}{|c|}{5400} \\
\hline
\end{tabular}

Table 3--Elasticity of Non-Exclusive Dealing

Consequently, the responsiveness to Identity Wholesaler's 1's price cut under nonexclusive dealing is more elastic in the market as a whole (5300 to 5400) than under exclusive dealing. ${ }^{61}$ Once again, the consequences of inelasticity are important when there is a loss of monopoly control, because it indicates how precipitous the drop in loyalty in the market will be. ${ }^{62}$

In effect, exclusive dealership agreements produce less elastic demand curves than non-exclusive arrangements with respect to retail markets. The same is true with respect to wholesalers. Under non-exclusive dealerships, wholesalers who do not react to their competitors' price changes will find that their own products do not sell in the wholesale market. However, under exclusive relationships, the wholesaler is shielded

exclusive dealing than under non-exclusive dealing. The competition among a larger number of dealers would tend to reduce retail prices." Lin, supra note 55, at 211 . Iraq has an estimated 23 tribal confederations, collectively constituting over 100 tribes. Susan Sachs, The Sheik Takes Over: In Iraq's Next Act, the Tribes May Play the Lead Role, NEW York TIMES, June 6, 2004, at ___. The presence of so many tribes within Iraq should operate to drive down retail prices, but only assuming competition for loyalty suppliers and for tribal members. See infra note 63.

${ }^{60}$ This is true for the same reasons in the exclusive-dealing arrangement. See supra note 56.

${ }^{61}$ See Lin, supra note 55, at 210 ("The overall effect is that the perceived demands of the manufacturers are rendered more inelastic under exclusive dealing, much as if the products had been differentiated.").

${ }^{62}$ See supra section entitled, 1. The Basics of Elasticity. 
to some extent by the actions of its exclusive retailer, which cuts prices, and absorbs the financial impact to avoid losing customers to another retailer.

\section{c. Exclusive Dealing without Consumer Mobility}

The scenarios above have assumed mobility of customers or tribal members among tribal retailers. However, tribal members probably cannot change their tribal membership, except perhaps through marriage. ${ }^{63}$ Lacking mobility, the market becomes yet even more inelastic under exclusive dealing. In such instances, the retail price of Identity Product 2 would not be reduced at all to keep tribal customers from fleeing from Tribal Retailer 2 to Tribal Retailer 1. In essence, the line represented by $A$ to $B^{\prime}$ in Figure 3 would be essentially vertical (although there might be some slope to the right because of increased consumption by the members of Tribe 1 in response to the lower price, but there would be no new customers). See Figure 4 below.

\footnotetext{
${ }^{63}$ See supra note 6 . While an individual may not easily change his or her tribal affiliation, it does happen. See supra note 52 and accompanying text.Error! Bookmark not defined. In fact, kinship with a particular tribe may be fictional. Lévi-Straus contended that "kinship structures" often depend on the relationships of "brothers-in-law" and that the system "does not consist in objective ties of descent or consanguinity between individuals. It exists only in human consciousness; it is an arbitrary system of representations, not the spontaneous development of a real situation." CLAUDE LÉVI-STRAUS, STRUCTURAL ANTHROPOLOGY 50 (Claire Jacobson and Brooke Grundfest Schoepf, trans. 1963) (1958). See generally, Julian Pitt-Rivers, Kinship: Pseudo-kinship, in 8 INTERNATIONAL ENCYCLOPEDIA OF THE SOCIAL SCIENCES 408-13 (David L. Sills, ed. 1968) (using "figurative," "fictive or artificial," and "ritual" kinship as examples of pseudo-kinship). Furthermore, tribes have been "manufactured" to meet the needs of Hussein régime. See Yaphe, supra note 33, at___ ("[T]he government allowed the manufacture of new 'tribal' groups based on economic ties or greed. ... Instead of common lineage, territory and a more agrarian livelihood .... the new tribes are led by educated, middleclass professionals, and civil servants who rent apartments in the city.").
} 


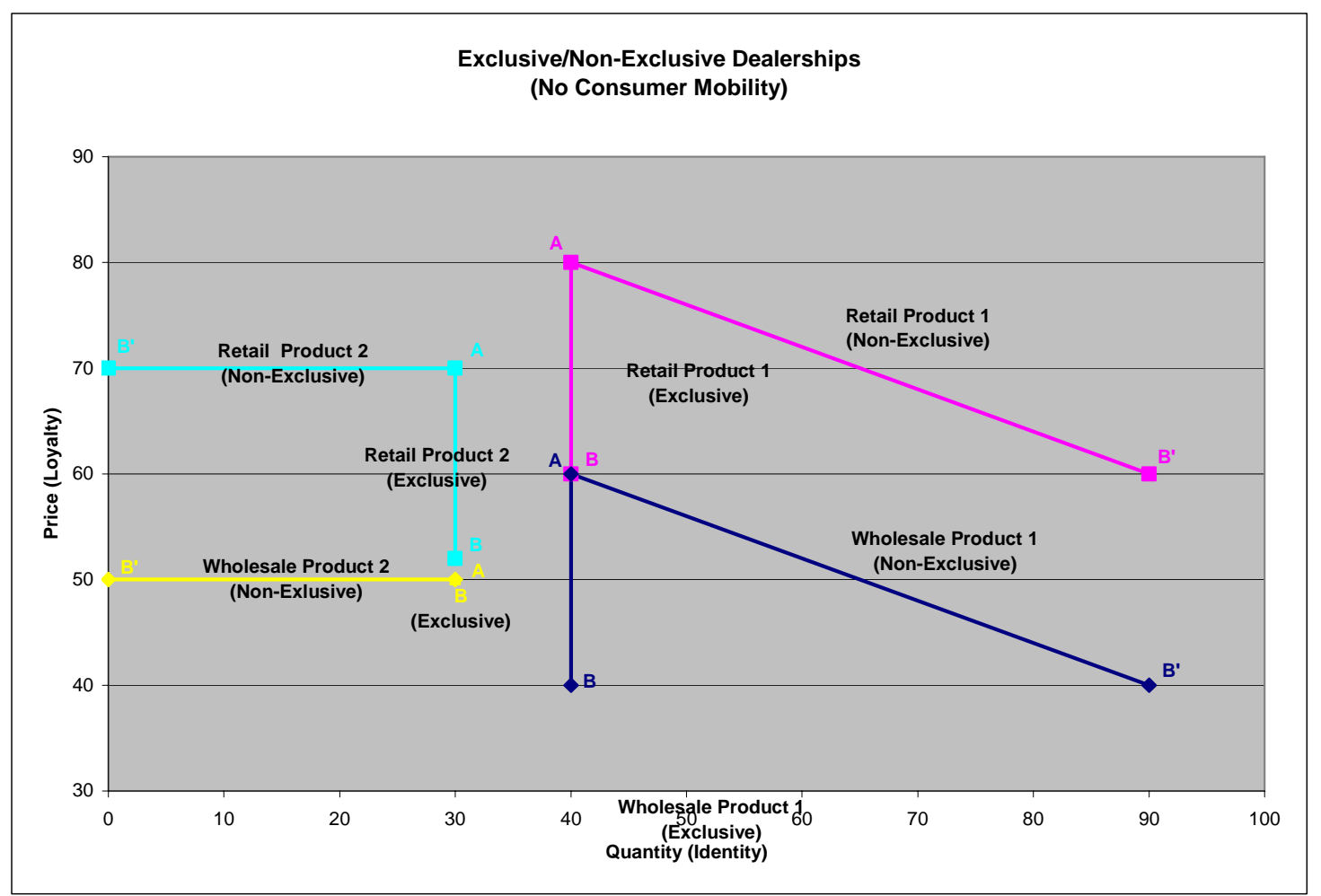

Figure 4

In effect, tribal retailing of this type of exclusive-dealing environment represents the most inelastic and destabilizing of all possible environments for Identity Wholesalers. ${ }^{64}$

\section{iv. Time, Information Barriers and Transaction Costs}

Over time, the demand curves tend to become more elastic. ${ }^{65}$ This is partly because transaction costs (even if possible, switching tribal allegiances, for instance in the case of marriage, may result in shunning and economic boycott by family and acquaintances) exist for switching loyalties to substitutes, ${ }^{66}$ and it may take time for consumers to be aware of the presence of substitutes in the marketplace. ${ }^{67}$

${ }^{64}$ For discussion of the ability of tribal members to switch allegiance, see supra notes 6 and 63

${ }^{65}$ See GeOrge J. Steiger, THE TheORY OF PRICE 45-47 (rev. ed. 1952) ("This belief rests chiefly on the pervasive potentialities of substitution, which, for example, have consigned to failure every attempt to defeat an enemy in wartime by destroying some allegedly indispensable resource or product .....").

${ }^{66}$ Id. at 45 (technological restrictions to switching consumption among substitutes). See also id. at 46 (habit and the inertial of readjusting budgets for different purchasing patters).

${ }^{67}$ Id. at 46 ("A price reduction may not be known to all consumers immediately so its full effects will not be realized immediately."). 
"Unstandardized commodities that are purchased infrequently (houses, furs) may be considerably affected by it. Buyers may also delay shifting to another product until a price rise [or decrease in the substitute commodity] appears to be permanent." ${ }^{\prime \prime}$ In the case of occupied Iraq, switching loyalties may have significant transaction costs (the pains of severing social and family relations, readjusting orientation, and reallocating budgeted loyalties, etc.), which may not be worthwhile, until the new supply of identity is seen as stable and at a permanently reduced price. Loyalty to the democratic institutions, supported by U.S. efforts may not present Iraqis with a secure and stable sense of identity - so why bother switching suppliers in light of the costs. Furthermore, there may be no "going back" (at least not without significant cost) to old suppliers if the new supplier of identity suddenly folds. Misperceptions about the extant of loyalty demanded by new suppliers may also inhibit switching to new suppliers of identity.

\section{Importance of Elasticity--Summary}

Elasticity is what determines the extent of destabilization following loss of monopoly control. Other factors being equal, on an inelastic demand curve, the price (loyalty) falls a greater amount to equilibrium than on an elastic demand curve. Factors determining the elasticity of the market demand curve include:

- the presence of substitutes (and competitors supplying substitutes) in the market;

- the closeness (and relative inferiority or superiority) of those substitutes the good (identity) whose price is falling;

- the number of marginal consumers drawn into the market after demonopolization;

- exclusive dealing agreements with intermediaries or retailers in the market;

- the presence of information barriers (as to price changes) and transaction costs, both of which need time to be overcome.

Essentially, competing substitute identities, which are similar to those in the market prior to de-monopolization, marginal consumers, the presence of a retail market with exclusive dealing arrangements, and the absence of transaction and informational barriers will render the market most elastic and least affected by loss of monopoly control.

These factors become extremely important as a nation such as Iraq emerges from under the hegemony of a tyrannical regime with monopolistic control over the information environment. Even if monopoly control over the market for loyalties is lost, these other factors relating to elasticity may keep loyalty prices artificially high, ultimately favoring fanatic devotion of small but violent segments of society and ensuing

${ }^{68} I d$. 
reassertion of oligarchic or monopoly control over the information environment and market for loyalties.

\section{Validity of the Application of Neo-Classical Economics to Information Studies}

Some have argued that certain aspects of individual behavior (even in the context of traditional markets) just cannot be explained by classical economic theory. Often these criticisms challenge assumptions of rationality. ${ }^{69}$ Ultimately, economics, like every other theory, is limited in what it can explain. ${ }^{70}$

Stephen Lubet, a law professor at Northwestern University, begins a wellreasoned article on the limits of economics with the statement: "Nothing can shake your faith in neoclassical economics so much as the visit to the Middle East." ${ }^{71}$ In his article, Professor Lubet describes in great detail his unsuccessful attempts to apply

\footnotetext{
${ }^{69}$ In modern economic theory, "collective action," "prisoner's dilemma" and "externalities" problems challenge the classical economic assumption that individuals will always make rational choices to maximize their interests. The trouble is that there is a "divergence between individual and collective rationality" as noted in collective action and prisoner's dilemma problems. Anatol Rapoport, Prisoner's Dilemma, in 1 New Palgrave Dictionary of Econ. 973, 974 (1987, rev. 1991). See also Mancur Olson, Collective Action, in 3 NeW PALgRAVE Dictionary of ECON. 474 (1987, rev. 1991). This quandary is not simply speculative in nature, but a practical problem that has been duly noted in the debate surrounding the government's need to mandate public interest television.

... [P]ublic interest programming can produce social benefits that will not be adequately captured by the individual choices of individual citizens; the same is true for programming that produces social costs, including apathy, fear, and increased criminal activity. Because of the collective action problem, an unregulated market will underproduce public goods and overproduce public bads.
}

Cass R. Sunstein, Television and the Public Interest, 88 CAL. L. REV. 499, 517 (2000).

Applying the analysis of collective action and externalities problems, the explanation for government effort to regulate information flow stems from the need to protect the demand for its public goods (i.e., it is in the public's interest to receive a uniform message from broadcasters and publishers supporting policies and values approved by the state), rather from a drop in price (in terms of loyalty) as in Professor Price's market for loyalties theory. The problem with this analysis is that oppressive régimes and oligarchs who monopolize the market for loyalties do not act in such a way as to maximize "public goods."

${ }^{70}$ See, e.g., Richard B. McKenZIE, The Limits of EConomic SCIENCE 27 (1983).

My concern is . . . that we [economists] have lost sight of the limitations of our methods and, thereby, the limited applicability of the conclusions that have been drawn. More specifically, in much modern discussion, economists seem to have made an unrecognized intellectual leap from assuming that the individual has a rational capacity to assuming that all individual behavior has a rational foundation and is therefore subject to logical discourse.

Id.

\footnotetext{
${ }^{71}$ Steven Lubet, Notes on Bedouin Horse Trade or "Why Won't the Market Clear, Daddy?", 74
}

TEX. L. ReV. 1039 (1996). 
neoclassical economic theory on each of three separate occasions to negotiate a "bargain" fare for a horse ride out of a canyon containing the ruins of Petra, an ancient fortress city in Jordan. Applying classical economic analysis, Professor Lubet explores all the possible reasons that the "market failed to clear." ${ }^{72}$ After considering, and dismissing, all the possible economic factors--bad bargaining techniques, barriers to information flow, operation of a cartel, opportunity costs, etc. ${ }^{73}$--Professor Lubet turns to a non-economic explanation as to why his Bedouin guides would not accept his perfectly sensible offer (at least in economic terms):

From a common sense perspective, the answer is painfully obvious. Pride. They [the Bedouin] were desert horsemen, after all, and they probably were not thrilled about chauffeuring tourists in the first place. There was an amount of money that made work worthwhile, and they just were not interested in anything less, efficiency be damned. From an economic perspective, on the other hand, their behavior was irrational . . . .

The experience of the Bedouin has no doubt emphasized the value of pride, not to mention related virtues such as determination and group identification. During nomadic life, it seems likely that pride would be a positive survival feature because it makes one more willing to endure hardship, value each individual, and protect one's family and flock. In other words, the development of stubborn pride should be seen as an evolutionary adaptation to environmental circumstances. Is it possible that the laws of evolution, at least by analogy, might reveal an explanation that the laws of economics have failed to provide? ${ }^{74}$

As Professor Lubet points out, there are some behaviors (particularly irrational ones) hat traditional economics just does not explain. His reference to (and questioning of whether) the theory of evolution explains certain behaviors is significant. Evolution is about adaptation and survival, something with which governments and their constituent power holders are familiar, and with which they are often obsessed. The ultimate values driving human behavior in the theory of evolution are different. As Professor Lubet notes, "Adaptation, after all, tends only to ensure a level of survival, not to

\footnotetext{
${ }^{72}$ "Market clearing" refers to the equilibrium of supply and demand -- the point where a buyer and seller agree to an exchange. See id. at 1039.

${ }^{73}$ See id. at 1042-49.

${ }^{74} / d$. at $1050-51$. Besides criticisms made on the basis of the theory of evolution and the need to survive, other criticism points out the alleged "impoverished" nature of the economic model of humanity, specifically its failure to consider aesthetics:

"Law and economics" assumes human beings to be fundamentally rationally actors with economic desires. Such an impoverished understanding of human motivation and meaning explicitly eliminates the aesthetic dimension. ... "[L]aw and economics" has a weak understanding of human beings.

Desmond Manderson, Songs without Music, Aesthetic Dimensions of LaW And Justice 33 (2000).
} 
produce perpetually ideal results. In other words, evolution seeks viability, not optimality." ${ }^{, 75}$

However, Professor Lubet may have abandoned economics too soon. Professor Lubet's market involves the exchange of cash for service. But this is not the exchange that market for loyalties explains. It explains regulatory behavior on a more fundamental level-identity (which includes fears and hopes concerning survival) and loyalty. Recasting Lubet's troubled market at Petra in terms of market for loyalties theory would produce a very different analysis. Fundamentally, the Arab guides needed identity, even more than cash. Their own pride and sense of who they are kept them from provided services (or devoting their loyalty to tourists as their guides) for any amount below a certain rate. The Market did not clear because Lubet was dealing in the wrong currency. He might have gotten his ride for nothing if he could have tendered a heavy dose of identity instead of cold cash.

\section{Implications for US Information Policy in Occupied IRAQ}

Market for loyalties theory predicts destabilization following loss of monopoly control over an information environment. The destabilization is the result of governments and traditional power elites losing their ability to command the loyalty necessary to exact taxes, military service, commitments to law and order, etc. If, following loss of monopoly control, the market were to rapidly slide to equilibrium, the point where loyalty and identity are exchanged freely without artificial constraints, then the number of identity suppliers competing for loyalty would be such that the presence or absence of any single supplier should no longer have an significant impact on price, in terms of loyalty, and consequently no destabilizing effects.

However, there are a number of reasons why a market may not slide to equilibrium following the loss of control by a single or small group of identity suppliers. First, marginal consumers (previously excluded from the market because of price or other barriers, e.g., Kurds and Shiites) may flood the market and consequently, keep loyalty prices higher than expected after there is a loss of monopoly control. Second, the presence of wholesaler and retailers (in the form of tribal intermediaries) in the market may conspire to artificially keep prices high, especially if such identity suppliers have entered into exclusive dealing arrangements or are vertically integrated. Third, information barriers and steep transaction costs may make it difficult, if not impossible, for tribal members to switch tribal retailers and readjust their loyalties, especially if the long-term viability of a new supplier for identity is in doubt.

For U.S. policy in Iraq or in other formerly repressed states, there are some important lessons to be gleaned from market for loyalties theory:

\section{Importance of De-monopolization}

\footnotetext{
${ }^{75}$ See Lubet, supra note 71, at 1051.
} 
With the presence of each new purveyor of identity in the market place, the market should grow more stable, with less trauma from the addition or removal of any identity supplier. Consequently, the objective in a recently opened information environment, such as Iraq, is to push towards a market with as many identity suppliers-diverse political parties, consumer projects, schools, libraries, Internet cafes, and media outlets, etc.-as possible. Essentially, the freer the flow of information and expression, the better.

De-monopolization, or specifically, the removal of an oppressive régime, alone will not cause the emergence of a healthy information environment, conducive to democratic institutions. Other factors such as tribalism may keep demand for identity high, artificially inflate the price of loyalty, and favoring the predominance in the market by relatively few identity suppliers, who provide potent and radicalized messages of identity. These suppliers (terrorist groups, insurgents, etc.) demand a high price in terms of loyalty, which often must be demonstrated through acts of violence and repression. As a result, the removal of a single, controlling provider of identity from the market place, such as Saddam's régime, without any other measures, may not be effective.

The diminishment of the loyalty that terrorist, insurgent and other violent groups can command is essential. Redirection of loyalty into political expression, religious observance, careers, education, and material consumption all work to drive down the loyalty which violent groups can command.

Tribalism, particularly, when tribes deal in excusive relationships with governments or power groups, artificially holds loyalty prices high and creates "loyalty barriers" for their members, who are not completely free to switch allegiances without dire repercussions. Such tribalism can facilitate the very conditions that terrorists, insurgents and other violent groups, which are dependent upon extreme loyalty from their members, can best operate. Consequently, efforts must be made to reduce exclusive dealing relationships among tribes and to permit tribal members more fluidity in their relationships and affiliations.

\section{Importance of Identity.}

Nothing fosters loyalty like identity. In its actions and communiqués, the U.S. must employ symbols and language emphasizing a strong sense of Iraq's heritage, accomplishments, culture and future, at every opportunity. It must provide support and training to pro-democratic Iraqi leaders to do the same. Iraq should be consistently referred to as the "cradle of civilization," and as the "People of Abraham" to strengthen relationships with the West. Particular effort should be made to foster the emergence of a new, democratic Iraqi identity. For example, the image of the common Iraqi with a purple finger (signifying individual vote) should be plastered all over Iraq until it is firmly embedded in every Iraqi's psyche.

As a corollary to fostering Iraqi identity, every effort must be made to distinguish violent and repressive groups as at odds with Iraqi identity, and inconsistent with Islam, the "Spirit of Abraham" and civilized society. Furthermore, access of moderate voices to the market for loyalties must be protect, and if necessary, aided. 


\section{Importance of an Open Market over Message}

The U.S. objective is not to win Iraqi loyalty for itself, but to create, maintain, and if necessary, police a market of competing identities, where there is enough diversity of supply that Iraq is stabilized, and no longer at risk from violent messages of religious extremists, insurgents or other groups.

The three preceding policy recommendations do not constitute a comprehensive plan for the administration of IRAQ or counterinsurgency. Such a plan would be beyond the scope of this Article and expertise of the author. Montgomery McFate and Andrea Jackson, both specialists in cultures and insurgencies, ${ }^{76}$ have articulated a more complete set of "tools" to address insurgencies: "coercive force, economic incentives and disincentive, legitimating ideology, and traditional authority." 77 However, all of these tools, bear relationships with market for loyalties theory. As demonstrated by McFate and Jackson, coercive force must be limited because the "central goal of an insurgency is not to defeat the armed forces, but to subvert or destroy the government's legitimacy, its ability and moral right to govern."78 In other words, the war is about loyalty. Indeed legitimacy is closely tied to concepts of identity-the relationship of subjects to their sovereign state. Security is also an important function of coercive force. "[Vietnamese peasants] will support the government if and when they are convinced it offers them a better life, and can and will protect them against the [guerrillas] . . . forever." ${ }^{79}$ A fearful future, or freedom there from, constitutes and important part of an individual's identity. ${ }^{80}$ "Freedom from fear" as articulated by Franklin Roosevelt, ${ }^{81}$ was an important part of the U.S. effort to instill loyalty and bolster national identity during World War II.

Continuing further with McFate and Jackson's tools-and their relationship to market for loyalties_-policies, including "economic incentives," must consider that beyond cash and other tangible benefits, humans have a fundamental need for identity that guides their choices in ways confounding traditional economics. ${ }^{82}$ Even when

${ }^{76}$ See supra notes 30 and 31 .

${ }^{77}$ McFate and Jackson, supra note 33, at 2-3.

${ }^{78}$ Courtney E. Prisk, The Umbrella of Legitimacy, in UNCOMFORTABLE WARS: TOWARD A NEW PARADIGM OF LOW INTENSITY CONFLICT 69 (Max G. Manwaring, ed. 1991) (cited in McFate and Jackson, supra note 33 , at 5).

${ }^{79}$ Charles Simpson, Inside the GREen Berets: The FIRSt ThiRTY YeARS 62 (1982) (cited in McFate and Jackson, supra note 33, at 5).

${ }^{80}$ See McFate and Jackson, supra note 33, at 14.

${ }^{81}$ Proclamation No. 2570, 7 Fed. Reg. 222 (Nov. 11, 1942). The "Four Freedoms" were first articulated in a presidential address to Congress on Jan. 6, 1941. See FRANKLIN D. ROOSEVELT PRESIDENTIAL LIBRARY AND MUSEUM, OUR DOCUMENTS: FRANKLIN ROOSEVELT'S ANNUAL AdDRESS to CONGRESS - THE "FOUR FREEDOMS", Jan. 6, 1941, http://www.fdrlibrary.marist.edu/od4freed.html (includes audio broadcast and text).

${ }^{82}$ See e.g., supra notes 71-75 (example of Bedouin guides at Petra in Jordan). 
considering traditional economics (cash, goods, services, standard of living, etc.), individuals often invest in the future, assigning loyalty to the groups and causes most likely to pay off in the long run. As already described above, "ideology" as a tool for legitimization is closely connected with identity and a key tool for instilling loyalty. ${ }^{83}$ Finally, "traditional authority" is intimately connected with the symbology of identity. McFate and Jackson describe the power of symbols in legitimating authority of Ho Chi Minh in Viet Nam by:

Facing the prospects of losing his throne or his life, the Emperor resigned and presented Ho Chi Minh with the imperial sword and sacred seal, there by investing him with the 'mandate of heaven' . . . the ultimate form of traditional authority. Subsequently, Ho ruled Vietnam as if he were an emperor possessed of a heavenly mandate, replicating many of the signs and signals of Vietnamese traditional authority. ${ }^{84}$

The path to establishing authority often involves ritual and powerful manipulation of historical, religious and cultural signs--hence, statements like "[t]o defeat the insurgent narratives, the Coalition must generate strong counter-narrative." ${ }^{85}$ Perhaps so, but this Article's crowning thesis, and the final U.S. policy recommendation set forth above, prioritizes sustaining an open information market, rather than exclusively pinning hopes on winning the "hearts and minds" of the Iraqi people, as a more productive and achievable policy objective.

\section{Conclusion}

Essentially, economic theory, and more specifically information economics and market for loyalties theory, have demonstrated the wisdom and benefit of a freedom of speech and information flow, as well as highlight some of the factors impacting the realization of a stable information environment. During World War II, an important case involving the right not to salute the flag led Supreme Court Justice Robert H. Jackson (soon to become the lead prosecutor at the War Crimes Tribunals at Nuremberg), articulated the fundamental axiom, of US Constitutional law: "If there is any fixed star in our constitutional constellation, it is that no official, high or petty, can prescribe what shall be orthodox in politics, nationalism, religion, or other matters of opinion or force citizens to confess by word or act their faith therein." ${ }^{86}$ Not only do freedoms of speech, press, and religion constitute the "fixed star" of democracy, they are essential to

${ }^{83}$ See supra notes $14,32-36$ and accompanying text.

${ }^{84}$ McFate and Jackson, supra note 33, at 26.

${ }^{85} \mathrm{Id}$. at 20. See also supra notes $32-36$ and accompanying text. As a result, the US Army has developed considerable interest in understanding "adversary culture." See, e.g., Montgomery McFate, The Military Utility of Understanding Adversary Culture, JOINT FORCE Q., No. 38, $3^{\text {rd }}$ quarter 2005, at 42, available at http://www.dtic.mil/doctrine/jel/jfq_pubs/0438.pdf; Montgomery McFate, Anthropology and Counterinsurgency: The Strange Story of their Curious Relationship, MIL. REV., Mar.-Apr. 2005, at 24.

${ }^{86}$ West Virginia State Board of Education v. Barnette, 319 U.S. 624, (1943) (Jackson, J.) 
harmony and stability, and consequently must be a cornerstone of U.S. policy. There is no going back from the brink of democracy. While tribalism and repressive ideologies hinder the establishment of a stable market for loyalties in Iraq and Middle East, steps may be taken to mitigate these inhibitors. Wherever the U.S. seeks to exert its influence, the market for loyalties, and information environment, must become open and free. 